\title{
Tracing the origin and geographic distribution of an ancestral form of the modern human Y chromosome
}

\author{
Reconstrucción del origen y distribución geográfica de una forma ancestral del \\ cromosoma $\mathrm{Y}$ del hombre moderno
}

CLAUDIO M.' BRAVI, GRACIELA BAILLIET, VERÓNICA L. MARTÍNEZ-MARIGNAC \& NESTOR O. BIANCHI ${ }^{2}$

\author{
${ }^{1}$ Multidisciplinary Institute of Cell Biology (IMBICE), CC 403, 1900 La Plata, Argentina \\ ${ }^{2}$ Corresponding author: IMBICE, Calle 526 e/10 y 11, 1900 La Plata, Argentina \\ e-mail: bianchi@satlink.com
}

\begin{abstract}
We screened a total of $841 \mathrm{Y}$ chromosomes representing 36 human populations of wide geographical distribution for the presence of a Y-specific Alu insert (YAP+ chromosomes). The Alu element was found in 77 cases. We tested five biallelic and eight polyallelic markers in 70 out of the 77 YAP+ chromosomes. We could identify the existence of a hierarchical and chronological structuring of ancestral and derived YAP+ lineages giving rise to four haplogroups, 14 subhaplogroups and 60 haplotypes. Moreover, we propose a monophyletic origin for each one of the YAP+ lineages. Out-of-Africa and out-of-Asia models have been suggested to explain the origin and evolution of ancestral and derived YAP+ elements. We analyse the evidence supporting these two hypotheses and we conclude that the information available supports better the out-of-Africa model.
\end{abstract}

Key words: YAP+ chromosomes, YAP+ lineages, Y-specific Alu inserts.

\section{RESUMEN}

Se buscó la presencia de un inserto Alu Y-específico (cromosomas YAP+) en un total de 841 cromosomas Y provenientes de 36 poblaciones humanas de amplia distribución geográfica. El elemento Alu se encontró en 77 casos. En 70 de los 77 cromosomas YAP+ se testificaron cinco marcadores bialélicos y ocho polialélicos. Se pudo identificar la existencia de una estructura jerárquica y cronológica de linajes YAP+ ancestrales y derivados, la cual generó cuatro haplogrupos, 14 subhaplogrupos, y 60 haplotipos. Se propone un origen monofilético para cada linaje YAP+. Dos modelos intentan explicar el origen y evolución de los cromosomas YAP+ ancestrales y derivados: (i) origen del inserto Alu en Africa y posterior migración a otros continentes ("out-of-Africa"); (ii) origen en Asia con subsecuente migración a otras áreas geográficas ("out-of-Asia"). El análisis de la evidencia que apoya estos dos modelos nos permite sugerir que la hipótesis más probable es el origen africano con subsecuente dispersión fuera de Africa.

Palabras clave: cromosomas YAP+, linaje YAP+, inserto Alu Y-específico.

\section{INTRODUCTION}

Alu repeats are short interspersed elements (SINE) with nearly $10^{6}$ dispersed copies representing about $5 \%$ of the genetic material in primates (Schmid \& Maraia 1992). These mobile inserts have several interesting properties. First, they generate biallelic polymorphisms (absence/presence of the insert) that can be easily typed by PCR. Second, they are stable and unique in such a way that all individuals sharing the same Alu insert can be traced back to a single and common ancestor in which the insertion occurred for the first time. Third, the absence of the insert is always the ancestral state.

Alu repeats are approximately $300 \mathrm{bp}$ long and are characterized by the presence of a RNA pol III start site at the $5^{\prime}$ end, and by an A-rich tail at the 3 'end. Moreover, these repeats are usually grouped into subfamilies of different age. Alu elements accumulate mutations during evolution, with older Alus exhibiting the highest number of changes (Schmid \& Maraia 1992). Thus, the identification of a given repeat and the determination of the sequence of mutations within the Alu domain serve to reconstruct the phylogenetic history of the transposon.

Several Alu inserts known to occur in humans after the human/ape divergence have been extensively used to infer the evolution of modern human populations (Batzer et al. 1994, Hammer 1994, 1995, Whitfield et al. 1995, Stoneking et al. 1997). Among these human specific elements, one of them is particularly interesting due to its 
location in the non-recombinant region (DYS287 locus) of the human $\mathrm{Y}$ chromosome. YAP+ and YAP-acronyms identify the presence or absence (ancestral state) of the insert, respectively (Hammer 1994, Spurdle et al. 1994).

The $\mathrm{Y}$-specific region of $\mathrm{Y}$ chromosomes is haploid and patrilineally transmitted along generations. As this region does not undergo recombination, all Y-specific genes and markers are in linkage disequilibrium with mutations being the only potential source of variation between the male ancestor and his male offspring.

$\mathrm{YAP}+$ chromosomes appear at low frequency $(<10 \%)$ in some Asian, Oceanian and Amerindian populations, at intermediate frequency (11-30\%) in Caucasians and Japanese, and at high frequency $(>31 \%)$ in Tibetans and several African populations (Hammer 1994, Spurdle et al. 1994, Altheide \& Hammer 1997, Bianchi et al. 1997, Karafet et al. 1997, Hammer et al. 1998, Thomas et al. 1998). Since its origin, this Alu domain accumulated several biallelic additional mutations: two $\mathrm{C}>\mathrm{T}$ transitions at $338 \mathrm{bp}$ (PN1) and 1,682 bp (PN2) loci, and a deletion of the poly A tail ( $\mathrm{S}$ for short tail). Finally, outside the Alu domain, two other mutations, a $\mathrm{G}>\mathrm{A}$ transition at 4,064 bp of the SRY domain (Whitfield et al. 1995) and an A $>\mathrm{G}$ transition at 168 bp position of the DYS271 locus (Seielstad et al. 1994) were also informative (Hammer 1995, Altheide \& Hammer 1997, Bravi et al. 1997b).

Besides the above biallelic loci we analyse here eight additional polyallelic Y-specific markers (one alphoid and seven microsatellite variants) in order to obtain a further insight on the origin and evolution of YAP+ lineages. The use of these markers allows us to identify YAP+ haplogroups, subhaplogroups and haplotypes to establish the monophyletic origin of the lineages and to asses the hypotheses regarding the geographic origin and age of the ancestral YAP+ chromosome.

\section{MATERIAL AND METHODS}

We studied a total of $841 \mathrm{Y}$ chromosomes representing different populations and geographic regions. Details of the populations analysed are given in Table 1. Allele DYS 199*T is specific of native Americans (Underhill et al. 1996, Bianchi et al. 1998); $64 \%$ of the Amerindian Y chromosomes in our series showed this marker. In this report, all cases of $\mathrm{YAP}+$ chromosomes in native Americans had the ancestral allele DYS $199 * \mathrm{C}$ indicating that these chromosomes are the result of European (haplogroup C) or African (haplogroup D) admixture.
Samples were provided by $\mathrm{M}$. Hammer (one Tibetan and one Japanese, one Bantu and two Gambians), Y-F Chris Lau (20 Chinese and all Laotians, Cambodians, Thai, Vietnamese and Philipinnes), M. Sans (AfroUruguayans), G. Cantos (AfroEcuadorians), R. Herrera (AfroUSA, Pakistanis and Bengalis, Chimila, Maya, Zuñi, Sioux, Navajo), J. Ferrer (Ayoreo and Lengua), P. Zukas (Mocovies), F. Rothhammer (Huilliche and Pehuenche), F. Carnese (Mapuche, Tehuelche, Wichi, Chorote and Toba), Nippon University Association of La Plata (12 Japanese), Lebanese Society of La Plata and Argentine Arab Home of Berisso (Lebanese), Syrian-Orthodox Association of La Plata (Syrians), Centre d'Etude du Polymorphismes Humains (CEPH pedigrees), Coriell (Pygmies and Melanesian) IMBICE DNA repository (La Plata and Jews). Coriell samples and samples donated by $\mathrm{M}$. Hammer were also included in series previously reported by Hammer et al. (1997, 1998). As far as we know CEPH samples were not tested before for YAP+ chromosomes. Therefore, 829 out of the 841 Y chromosomes tested for Alu inserts and the information on the ah system and microsatellites are new data produced by our group.

YAP+ and YAP- chromosomes were identified according to Hammer \& Horai (1995). All YAP+ cases were tested for ah variants (27 forms) (Santos et al. 1996), for SRY 4,064 (Whitfield et al. 1995), Poly-A tail, PN1, PN2 (Hammer 1995), and DYS271 (Seielstad et al. 1994) polymorphisms and for the allelic form of the following microsatellites: DYS 19 (tetranucleotide, 10 alleles), DYS389a (tetranucleotide, seven alleles), DYS389b (tetranucleotide, nine alleles), DYS390 (tetranucleotide, 10 alleles), DYS391 (tetranucleotide, six alleles), DYS392 (tetranucleotide, eight alleles), and DYS393 (trinucleotide, six alleles) (de Kniff et al. 1997, Kayser et al. 1997).

Alphoid (ah), DYS271 polymorphisms, and microsatellite allelic forms were tested as indicated in Seielstad et al. (1994), Santos et al. (1996), de Kniff et al. (1997) and Kayser et al. (1997). The A > G transition at 4,064 bp of the SRY domain (Whitfield et al. 1995) was determined by PCR using the pair of primers SRY3,920 (forward) 5'AGCACATTAGCTGGTATGACA - $3^{\prime}$ and SRY4,425 (reverse) 5' -CTCTTTATGGCAAGACTTACG -3', with $55{ }^{\circ} \mathrm{C}$ annealing temperature. After digestion of the PCR fragment with BsrBI, the ancestral allele (A) produces two restriction fragments of $359 \mathrm{bp}$ and $146 \mathrm{bp}$, while the derived allele generates a single fragment of 505 bp due to lack of restriction. The PN1 C $>\mathrm{T}$ transition was detected by PCR followed by restriction of the amplified fragment. Primers used were PN IF (for- 
ward) 5'-CATAATTTCATTTTCCCTATTGC-3', andPN1B(reverse) $5^{\prime}$-GTCCTCTCCTTATTAACGTAA$3^{\prime}$ with $55^{\circ} \mathrm{C}$ annealing temperature. After digestion with AluI, the $218 \mathrm{bp}$ amplicon results in two fragments of $145 \mathrm{bp}$ and $73 \mathrm{bp}$ if the derived $\mathrm{T}$ allele is present. The PN2 $\mathrm{C}>\mathrm{T}$ transition was detected by $P C R$ and restriction, using a mismatched primer in order to produce a new HaelII site exhibiting the polymorphism in the last $\mathrm{C}$ of the GGCC recognition site. The change of this $\mathrm{C}$ into $\mathrm{T}$ inhibits HaeIII digestion. Primers used were $\mathrm{PN} 2 \mathrm{~F}$ (forward) 5'. AGGAGCATTAATAAAACTAAgGC-3' ( $\mathrm{g}$ indicates the mismatch position) and $\mathrm{PN} 2 \mathrm{~B}$ (reverse) 5'-CTTCACTACCAGCCTAAGTAC -3', annealing temperature $56{ }^{\circ} \mathrm{C}$. Restriction in the ancestral allele produces $156 \mathrm{bp}$ and $22 \mathrm{bp}$ fragments; lack of restriction due to the $\mathrm{C}>\mathrm{T}$ transition generates a $178 \mathrm{bp}$ fragment. The test for the presence of a long (L) or short (S) Poly A tail was made by HaeIII restriction of the PCR fragment used for diagnosis of YAP+ chromosomes. In the presence of a $\mathrm{L}$ tail, the HaeIII fragments produced have $213 \mathrm{bp}, 80 \mathrm{bp}, 50 \mathrm{bp}$ and $130 \mathrm{bp}$; the size of the $130 \mathrm{bp}$ fragment decreases to $110 \mathrm{bp}$ if the tail is $S$. $L$ and $S$ alleles in this report correspond to the $\mathrm{L}$ (46 poly-A) and S (26 poly-A) of Hammer et al. (1997).

Microsatellite alleles in tables and text are identified by the number of repeats; the oh variants are identified with Roman numerals (Santos et al. 1996, Kayser et al. 1997). YAP+ haplogroups are identified by capital letters, subhaplogroups by Roman numerals and haplotypes by Arabic numerals. Three of our four YAP+ haplogroups correspond to the three YAP+ haplotypes reported by Hammer (1995) and Altheide \& Hammer (1997). We indicate in the text the correspondence between the two nomenclature systems.

\section{RESULTS}

We found 77 YAP+ chromosomes out of the 841 samples analysed. Table 1 illustrates the geographical origin of these 77 cases. Japanese and populations of African ancestry were the ones showing the highest frequencies of YAP+ chromosomes. In $70 \mathrm{YAP}+$ chromosomes we could make the full testing of the 13 polymorphic markers employed in this report; these are the cases included in Table 1.

SRY4,064, Poly-A, PN2, DYS271, and PN1 polymorphisms allowed to define four haplogroups $\mathrm{A}-\mathrm{D}$, which respectively correspond to haplotypes $3 \mathrm{G}, 3 \mathrm{~A}, 4 \mathrm{~A}$, and $5 \mathrm{~A}$ of Altheide \& Hammer (1997). The ancestral haplogroup A (3G)
TABLE 1

Origin of individuals analysed for Yap+
chromosomes

Origen de los individuos analizados para la presencia de cromosomas Yap+

\begin{tabular}{|c|c|c|}
\hline Population analysed & Y Chromosome & $\mathrm{YAP}+$ \\
\hline \multicolumn{3}{|l|}{ East Asians } \\
\hline Tibetan & 1 & 1 \\
\hline Japanese & 13 & 4 \\
\hline Chinese & 23 & 0 \\
\hline Laotian & 7 & 0 \\
\hline Cambodian & 3 & 0 \\
\hline Taiwanese & 1 & 0 \\
\hline \multicolumn{3}{|l|}{ South East Asians } \\
\hline Thai & 1 & 0 \\
\hline Philippine & 12 & 0 \\
\hline Vietnamese & 3 & 0 \\
\hline \multicolumn{3}{|l|}{ South Asians } \\
\hline Bengali & 61 & 0 \\
\hline Pakistani & 91 & 0 \\
\hline \multicolumn{3}{|l|}{ West Asians } \\
\hline Jew & 18 & 4 \\
\hline Syrian & 2 & 0 \\
\hline Lebanese & 6 & 0 \\
\hline \multicolumn{3}{|l|}{ Oceanians } \\
\hline Melanesian & 2 & 0 \\
\hline \multicolumn{3}{|l|}{ Africans } \\
\hline Bantu & 1 & 1 \\
\hline Gambian & 2 & 2 \\
\hline Pygmy & 5 & 2 \\
\hline Afro-Uruguayan & 17 & 7 \\
\hline Afro-Ecuatorean & 24 & 9 \\
\hline Afro-USA & 24 & 16 \\
\hline \multicolumn{3}{|l|}{ Europeans } \\
\hline CEPH & 68 & 3 \\
\hline \multicolumn{3}{|l|}{ South Americans } \\
\hline La Plata (admixed) & 199 & 22 \\
\hline \multicolumn{3}{|l|}{ Native Americans } \\
\hline Huilliche & 20 & 0 \\
\hline Pehuenche & 21 & 1 \\
\hline Mapuche & 27 & 2 \\
\hline Tehuelche & 16 & 0 \\
\hline Mocovi & 26 & 0 \\
\hline Wichi & 25 & 1 \\
\hline Chorote & 11 & 0 \\
\hline Toba & 6 & 1 \\
\hline Ayoreo & 10 & 0 \\
\hline Lengua & 30 & 0 \\
\hline Chimila & 12 & 1 \\
\hline Maya & 12 & 1 \\
\hline Sioux & 16 & 0 \\
\hline Zuñi & 16 & 0 \\
\hline Navajo & 10 & 0 \\
\hline Total & 841 & 77 \\
\hline
\end{tabular}


was characterized by the presence of ancestral alleles in all the above loci. Five $Y$ chromosomes belonged to this group (Table 2). A G > A transition in the SRY4,064 locus identifies the haplogroup B (3A), which comprises seven cases (Table 2). The 31 YAP+ cases in haplogroup C (4A) exhibited a S PolyA and the mutated allele PN2T (Table 2). Finally, the derived alleles DYS271G and PN1T identify the 27 YAP+ chromosomes in haplogroup D (5A) (Table 2). No cases with medium (M, 36bp) or very short (VS, 19bp) poly-A tails (Hammer et al. 1997) were detected in our series.

The $\alpha$ h system served to identify subhaplogroups within each haplogroup. We reported elsewhere that $\alpha \mathrm{hV}$ and aII are the only two forms present in both YAP+ and YAP-chromosomes, and that ahV is the ancestral state (Santos et al. 1996). Thus, we considered A1 $(\alpha \mathrm{hV})$ and A2 (ahII) as the ancestral and derived haplogroups, respectively (Table 2, Fig. 1). In haplogroup B, all cases were $\alpha \mathrm{hV}$; thus, subhaplogroup B1 was the only one detected in this set of YAP+ chromosomes (Table 2, Fig. 1). Alphoids $\alpha$ II, III, XII and XVI derive from $\alpha \mathrm{hV}$ through one (form III) or two deletions (form II), or via one mutation (forms XII and XVI) (Santos et al. 1996). Therefore, $\mathrm{C} 1(\alpha \mathrm{hV})$ is ancestral and $\mathrm{C} 2, \mathrm{C} 3, \mathrm{C} 4$ and $\mathrm{C} 5$ are the derived subhaplogroups (Table 2, Fig. 1).

Alphoid forms ahXXIII, XXVI and XXVII are known to derive from ahIX through deletions (ahXXIII) or point mutations ( $\alpha$ XXXVI-XXVII) (Santos et al. 1996, Bailliet unpublished results). Moreover, $\alpha$ hIX is known to be a derivative form of ahV (Santos et al. 1996). Thus, two different alternatives may explain the subhaplogroup pattern in haplogroup D: (a) $\alpha \mathrm{hV}$ is the ancestral form; in this case the lack of $\alpha \mathrm{hV}$ chromosomes in this haplogroup is due to lineage loss or to insufficient sampling; (b) the two mutations defining the group D (DSY271G and PN1T) occurred in an $\alpha$ hIX chromosome which is the ancestral form in this haplogroup. In the first alternative, the form ahII derives from $\alpha h V$ via two deletions, while in the second alternative ahII is assumed to be a derivative of $\alpha \mathrm{hXIV}$ via two deletions in the same two loci involved in the $\mathrm{V}>$ II change (Santos et al. 1996). Due to the high frequency of $\alpha \mathrm{hIX}$ chromosomes, we tentatively assume this form to be the ancestral one (DI subhaplogroup) (Table 2, Fig. 1).

The allele association for the seven microsatellite loci analysed allowed to identify the haplotypes within each subhaplogroup (Table 2 , Fig. 1). Since several individuals shared the same haplotypes (haplotypes $13,14,46,29$ and 43 were shared by 2, 2, 2, 4 and 5 males, respectively) we could only identify 60 different haplotypes out of the $70 \mathrm{Y}$ chromosomes analysed.

\section{DISCUSSION}

\section{Monophyletic origin of haplo and subhaplogroups}

The possibility of recurrence for Alu markers is almost null. Therefore, all YAP+ chromosomes are known to derive from a single individual in which the insertion took place for the first time (Hammer 1995).

Point mutations and deletions may be recurrent but the frequency of these phenomena is usually low enough as to be certain that most, if not all, the individuals in haplogroups $\mathrm{B}, \mathrm{C}$, and $\mathrm{D}$ derive also from the first individual who underwent the haplogroup-specific mutation. Haplogroups $\mathrm{C}$ and $D$ are peculiar in the sense that they are defined by the coexistence of two mutations: $S$ and $P N 2$ in the branching from $\mathrm{B}$ to $\mathrm{C}$, and DYS271 plus PN1 in the branching from $\mathrm{C}$ to $\mathrm{D}$ (Table 2, Fig. 1). In these cases it is clear that haplogroups C and D derived from the individual who had the second mutation in each pair of haplogroup-specific mutations.

If we combine the data in this paper with the data of Hammer et al. (1997), we have a total of 152 YAP+ chromosomes belonging to haplogroup $\mathrm{C}$ and $245 \mathrm{YAP}+$ chromosomes belonging to haplogroup D. These sample sizes are sufficient to ensure the detection of one of the two mutated alleles at a frequency of 0.0046 with $95 \%$ and 99 $\%$ confidence for haplogroups $\mathrm{C}$ and $\mathrm{D}$, respectively (Chakraborty 1992). Therefore, the presence of individuals showing only one mutation of the pair, in case they exist, should occur at frequencies lower than $4.6 \%$. Thus, there is a strong possibility that the extinction of the older lineage may be the cause explaining the apparent concurrence of two mutations in the branching of $B$ to $C$ and $\mathrm{C}$ to $\mathrm{D}$.

A direct assessment of the mutation rate of the alphoid system shows that the change of ah forms occurs at a rate lower than $1.6 \times 10^{-4}$ (Bianchi et al. 1998). Thus, most or all subhaplogroup lineages probably derive from single individuals who for the first time showed the change of one ah form to another.

The association of microsatellite alleles within each subhaplogroup produced 54 haplotypes that were individual-specific, and five haplotypes that were shared by 2 to 5 individuals (Table 2). Cases with equal YAP+ haplotypes were considered to derive from a common ancestor in spite of the fact 
TABLA 2

YAP+ haplogroups, subhaplogroups and haplotypes

Haplogrupos, subhaplogrupos y haplotipos YAP+

\begin{tabular}{|c|c|c|c|c|c|c|c|c|c|c|c|c|c|c|c|c|c|}
\hline $\begin{array}{l}\text { Haplo- } \\
\text { group }\end{array}$ & $\begin{array}{c}\text { SRY } \\
4.064\end{array}$ & Poly-A & PN 2 & DYS271 & PN I & $\begin{array}{c}\text { Sub- } \\
\text { aplogro }\end{array}$ & ah & 19 & $389 \mathrm{a}$ & $389 b$ & 390 & 391 & 392 & 393 & Frequency & $\begin{array}{l}\text { Haplo- } \\
\text { type }\end{array}$ & Origin \\
\hline & $\mathrm{G}$ & $\mathrm{L}$ & $\mathrm{C}$ & A & $\mathrm{C}$ & A 1 & V & 15 & 10 & 27 & 24 & 10 & 11 & 12 & 1 & 1 & Tibetan \\
\hline & $\mathrm{G}$ & L & C & A & C & A 2 & $\mathrm{Ii}$ & 16 & 10 & 27 & 25 & 10 & 11 & 13 & 1 & 2 & Japanese \\
\hline \multirow[t]{6}{*}{ A } & G & $\mathrm{L}$ & C & A & C & A 2 & II & 17 & 10 & 27 & 26 & 10 & 11 & 13 & 1 & 3 & Japanese \\
\hline & $\mathrm{G}$ & $\mathrm{L}$ & $\mathrm{C}$ & A & C & A 2 & II & 17 & 11 & 28 & 25 & 10 & 11 & 13 & 1 & 4 & Japanese \\
\hline & $\mathrm{G}$ & $\mathrm{L}$ & $\mathrm{C}$ & A & $\mathrm{C}$ & A 2 & II & 15 & 10 & 26 & 25 & 10 & 11 & 13 & 1 & 5 & Japanese \\
\hline & A & $\mathrm{L}$ & $c$ & A & C & B 1 & V & 14 & 9 & 25 & 25 & 10 & 11 & 13 & 1 & 6 & Pygmy \\
\hline & A & $\mathrm{L}$ & C & $\mathrm{A}$ & C & B I & V & 14 & 9 & 26 & 25 & 10 & 11 & 13 & 1 & 7 & Bantu \\
\hline & A & $\mathrm{L}$ & C & $A$ & $\mathrm{C}$ & B 1 & V & 14 & 9 & 25 & 24 & 10 & 11 & 13 & 1 & 8 & Afro-USA \\
\hline \multirow[t]{17}{*}{ B } & A & $\mathrm{L}$ & $\mathrm{C}$ & A & C & B I & V & 14 & 9 & 25 & 25 & 12 & 11 & 13 & 1 & 9 & Afro-USA \\
\hline & A & $\mathrm{L}$ & C & $A$ & $\mathrm{C}$ & $\mathrm{Bl}$ & V & 16 & 9 & 27 & 23 & 9 & 12 & 13 & 1 & 10 & La Plata \\
\hline & A & $\mathrm{L}$ & $\mathrm{C}$ & $A$ & $\mathrm{C}$ & B I & V & 14 & 11 & 29 & 25 & 10 & 11 & 13 & 1 & 11 & Gambia \\
\hline & A & $\mathrm{L}$ & $\mathrm{C}$ & A & $\mathrm{C}$ & B 1 & V & 15 & 8 & 27 & 23 & 10 & 11 & 13 & 1 & 12 & Afro-USA \\
\hline & A & $S$ & $\mathrm{~T}$ & A & $\mathrm{C}$ & $\mathrm{C} 1$ & V & 13 & 10 & 27 & 24 & 10 & 11 & 13 & 2 & 13 & La Plata (1), La Plata Jew(1) \\
\hline & A & $S$ & T & A & $\mathrm{C}$ & $\mathrm{C} 1$ & V & 13 & 10 & 27 & 23 & 10 & 11 & 13 & 2 & 14 & La Plata (1), La Plata Jew (1) \\
\hline & $\mathrm{A}$ & $S$ & $\mathrm{~T}$ & $A$ & $\mathrm{C}$ & $\mathrm{C} 1$ & $\mathrm{~V}$ & 13 & 10 & 28 & 24 & 9 & 11 & 13 & 1 & 15 & La Plata \\
\hline & $A$ & $S$ & $\mathrm{~T}$ & A & $\mathrm{C}$ & $\mathrm{Cl}$ & $V$ & 13 & 9 & 27 & 23 & 10 & 11 & 13 & 1 & 16 & Afro-USA \\
\hline & $A$ & $S$ & $\mathrm{~T}$ & A & $\mathrm{C}$ & $\mathrm{C} 1$ & V & 13 & 10 & 27 & 25 & 9 & 11 & 14 & 1 & 17 & La Plata Jew \\
\hline & A & $S$ & $\mathrm{~T}$ & A & $\mathrm{C}$ & $\mathrm{C} 1$ & V & 14 & 10 & 27 & 24 & 11 & 12 & 13 & 1 & 18 & Pehuenche \\
\hline & $\mathrm{A}$ & $S$ & $\mathrm{~T}$ & A & $\mathrm{C}$ & $\mathrm{Cl}$ & V & 14 & 10 & 29 & 24 & 10 & 11 & 13 & 1 & 19 & Mapuche \\
\hline & A & $S$ & $\mathrm{~T}$ & A & C & $\mathrm{C} 1$ & V & 13 & 11 & 28 & 25 & 10 & 11 & 13 & 1 & 20 & La Plata \\
\hline & A & $S$ & $\mathrm{~T}$ & A & C & C 1 & $V$ & 13 & 10 & 28 & 24 & 12 & 11 & 13 & 1 & 21 & La Plata \\
\hline & $A$ & $S$ & $\mathrm{~T}$ & A & $\mathrm{C}$ & $\mathrm{Cl}$ & V & 14 & 9 & 26 & 24 & 10 & 11 & 12 & 1 & 22 & CEPH \# 66 \\
\hline & A & $S$ & $\mathrm{~T}$ & A & $\mathrm{C}$ & $\mathrm{C} 1$ & V & 14 & 10 & 28 & 25 & 9 & 12 & 13 & 1 & 23 & La Plata \\
\hline & A & $S$ & $\mathrm{~T}$ & A & $\mathrm{C}$ & $\mathrm{C} 1$ & V & 15 & 9 & 26 & 24 & 10 & 11 & 12 & 1 & 24 & Afro-Uruguay \\
\hline & A & $S$ & $\mathrm{~T}$ & A & C & $\mathrm{Cl}$ & V & 13 & 11 & 28 & 25 & 9 & 11 & 14 & 1 & 25 & La Plata Jew \\
\hline \multirow[t]{17}{*}{ C } & A & S & $\mathrm{T}$ & A & $\mathrm{C}$ & $\mathrm{C} 2$ & III & 13 & 11 & 28 & 24 & 9 & 12 & 13 & 1 & 26 & La Plata \\
\hline & A & $S$ & $\mathrm{~T}$ & A & $\mathrm{C}$ & C 3 & II & 13 & 11 & 26 & 24 & 9 & 11 & 13 & 1 & 27 & La Plata \\
\hline & A & $S$ & $\mathrm{~T}$ & A & C & C 3 & II & 13 & 11 & 27 & 24 & 9 & 11 & 13 & 1 & 28 & La Plata \\
\hline & $\mathrm{A}$ & $S$ & $\mathrm{~T}$ & A & $\mathrm{C}$ & $\mathrm{C} 4$ & XII & 13 & 10 & 27 & 24 & 10 & 11 & 13 & 4 & 29 & La Plata (3),Wichi(1) \\
\hline & $\mathrm{A}$ & $S$ & $T$ & $\mathrm{~A}$ & $\mathrm{C}$ & $\mathrm{C} 4$ & XII & 13 & 10 & 27 & 23 & 10 & 11 & 13 & 1 & 30 & La Plata \\
\hline & A & $S$ & $\mathrm{~T}$ & A & $\mathrm{C}$ & $\mathrm{C} 4$ & XII & 13 & 11 & 28 & 24 & 10 & 11 & 13 & 1 & 31 & La Plata \\
\hline & A & $S$ & $\mathrm{~T}$ & A & $\mathrm{C}$ & $\mathrm{C} 4$ & XII & 13 & 9 & 26 & 24 & 10 & 11 & 13 & 1 & 32 & La Plata \\
\hline & A & S & $\mathrm{T}$ & A & $\mathrm{C}$ & $\mathrm{C}_{4}$ & XII & 13 & 10 & 27 & 23 & 11 & 11 & 13 & 1 & 33 & La Plata \\
\hline & A & S & $\mathrm{T}$ & A & $\mathrm{C}$ & $\mathrm{C} 4$ & XII & 14 & 11 & 27 & 25 & 10 & 11 & 14 & 1 & 34 & CEPH \# 1423 \\
\hline & A & $S$ & $\mathrm{~T}$ & A & C & C 5 & XVI & 13 & 11 & 27 & 23 & 9 & 11 & 13 & 1 & 35 & La Plata \\
\hline & A & S & $\mathrm{T}$ & A & $\mathrm{C}$ & C 5 & XVI & 13 & 11 & 27 & 25 & 9 & 11 & 13 & 1 & 36 & La Plata \\
\hline & A & $S$ & $T$ & $\mathrm{~A}$ & C & C 5 & XVI & 13 & 11 & 26 & 24 & 9 & 11 & 13 & 1 & 37 & La Plata \\
\hline & A & $S$ & $\mathrm{~T}$ & A & C & $\mathrm{C} 5$ & XVI & 13 & 10 & 26 & 24 & 10 & 11 & 13 & 1 & 38 & Mapuche \\
\hline & A & S & $\mathrm{T}$ & G & $\mathrm{T}$ & D 1 & IX & 15 & 10 & NULL & 21 & 10 & 11 & 13 & 1 & 39 & Afro-Uruguay \\
\hline & A & $S$ & $\mathrm{~T}$ & $G$ & $\mathrm{~T}$ & D I & IX & 15 & 11 & 28 & 21 & 10 & 11 & 14 & 1 & 40 & Afro-USA \\
\hline & A & $s$ & $\mathrm{~T}$ & G & $\mathrm{T}$ & D I & IX & 15 & 10 & 28 & 21 & 10 & 11 & 13 & 1 & 41 & Afro-USA \\
\hline & A & $S$ & $\mathrm{~T}$ & G & $\mathrm{T}$ & D 1 & IX & 15 & 10 & 27 & 21 & 10 & 11 & 14 & 1 & 42 & Chimila \\
\hline \multirow[t]{18}{*}{ D } & A & $S$ & $\mathrm{~T}$ & G & $\mathrm{T}$ & D 1 & IX & 16 & 11 & 28 & 21 & 10 & 11 & 14 & 5 & 43 & Afro-Ecuador \\
\hline & A & $S$ & $\mathrm{~T}$ & G & $\mathrm{T}$ & D 1 & IX & 16 & 9 & 28 & 21 & 10 & 11 & 14 & 1 & 44 & Afro-USA \\
\hline & A & S & $\mathrm{T}$ & G & $\mathrm{T}$ & D 1 & IX & 15 & 11 & 29 & 21 & 10 & 11 & 14 & 1 & 45 & Afro-USA \\
\hline & A & $S$ & $\mathrm{~T}$ & G & $\mathrm{T}$ & D 1 & IX & 17 & 10 & 28 & 21 & 10 & 11 & 14 & 2 & 46 & Afro-Ecuador, Afro-Usa \\
\hline & $\mathrm{A}$ & $S$ & $\mathrm{~T}$ & G & $\mathrm{T}$ & D 1 & IX & 15 & 10 & 28 & 21 & 11 & 11 & 13 & 1 & 47 & Afro-Ecuador \\
\hline & A & $S$ & $\mathrm{~T}$ & G & $\mathrm{T}$ & D 1 & IX & 15 & 10 & 27 & 22 & 10 & 11 & 13 & 1 & 48 & Afro-Ecuador \\
\hline & $\mathrm{A}$ & $S$ & $\mathrm{~T}$ & $\mathrm{G}$ & $\mathrm{T}$ & D 1 & IX & 16 & 11 & 28 & 22 & 10 & 11 & 14 & 1 & 49 & Afro-USA \\
\hline & A & $S$ & $\mathrm{~T}$ & $\mathrm{G}$ & $\mathrm{T}$ & D 1 & IX & 17 & 10 & NULL & 20 & 10 & 11 & 14 & 1 & 50 & Afro-USA \\
\hline & A & $S$ & $\mathrm{~T}$ & $\mathrm{G}$ & $\mathrm{T}$ & D I & IX & 17 & 10 & 27 & 21 & 10 & 11 & 14 & 1 & 51 & Afro-USA \\
\hline & A & $S$ & $\mathrm{~T}$ & G & $\mathrm{T}$ & D 1 & IX & 15 & 10 & 27 & 21 & 10 & 13 & 15 & 1 & 52 & Afro-Uruguay \\
\hline & $\mathrm{A}$ & S & $\mathrm{T}$ & G & $\mathrm{T}$ & D 1 & IX & 15 & 10 & 26 & 21 & 10 & 12 & 15 & 1 & 53 & CEPH \# $106^{\circ}$ \\
\hline & $\mathrm{A}$ & $S$ & $\mathrm{~T}$ & $\mathrm{G}$ & $\mathrm{T}$ & D 1 & IX & 18 & 10 & 28 & 21 & 10 & 11 & 12 & 1 & 54 & Afro-Uruguay \\
\hline & A & $S$ & $\mathrm{~T}$ & $\mathrm{G}$ & $T$ & D I & IX & 17 & 10 & 27 & 21 & 10 & 11 & 14 & 1 & 55 & Afro-USA \\
\hline & $\mathrm{A}$ & S & $\mathrm{T}$ & G & $\mathrm{T}$ & D 2 & XXIII & 14 & 10 & 27 & $2 i$ & 10 & 11 & 15 & 1 & 56 & Toba \\
\hline & $A$ & $S$ & $\mathrm{~T}$ & $\mathrm{G}$ & $\mathrm{T}$ & D 3 & XXVI & 15 & 10 & 27 & 21 & 10 & 11 & 14 & 1 & 57 & Pygmy \\
\hline & $\mathrm{A}$ & S & $\mathrm{T}$ & $\mathrm{G}$ & $T$ & D 4 & XXVII & 15 & 10 & 27 & 21 & 10 & 11 & 14 & 1 & 58 & Maya \\
\hline & $A$ & S & $\mathrm{T}$ & $\mathrm{G}$ & $\mathrm{T}$ & D 5 & XIV & 15 & 10 & 28 & 21 & 10 & 11 & 13 & 1 & 59 & Afro-Ecuador \\
\hline & A & $S$ & $\mathrm{~T}$ & $\mathrm{G}$ & $\mathrm{T}$ & D 6 & II & 15 & 10 & 28 & 21 & 10 & 11 & 13 & 1 & 60 & Afro-USA \\
\hline Total & & & & & & & & & & & & & & & & 70 & \\
\hline
\end{tabular}



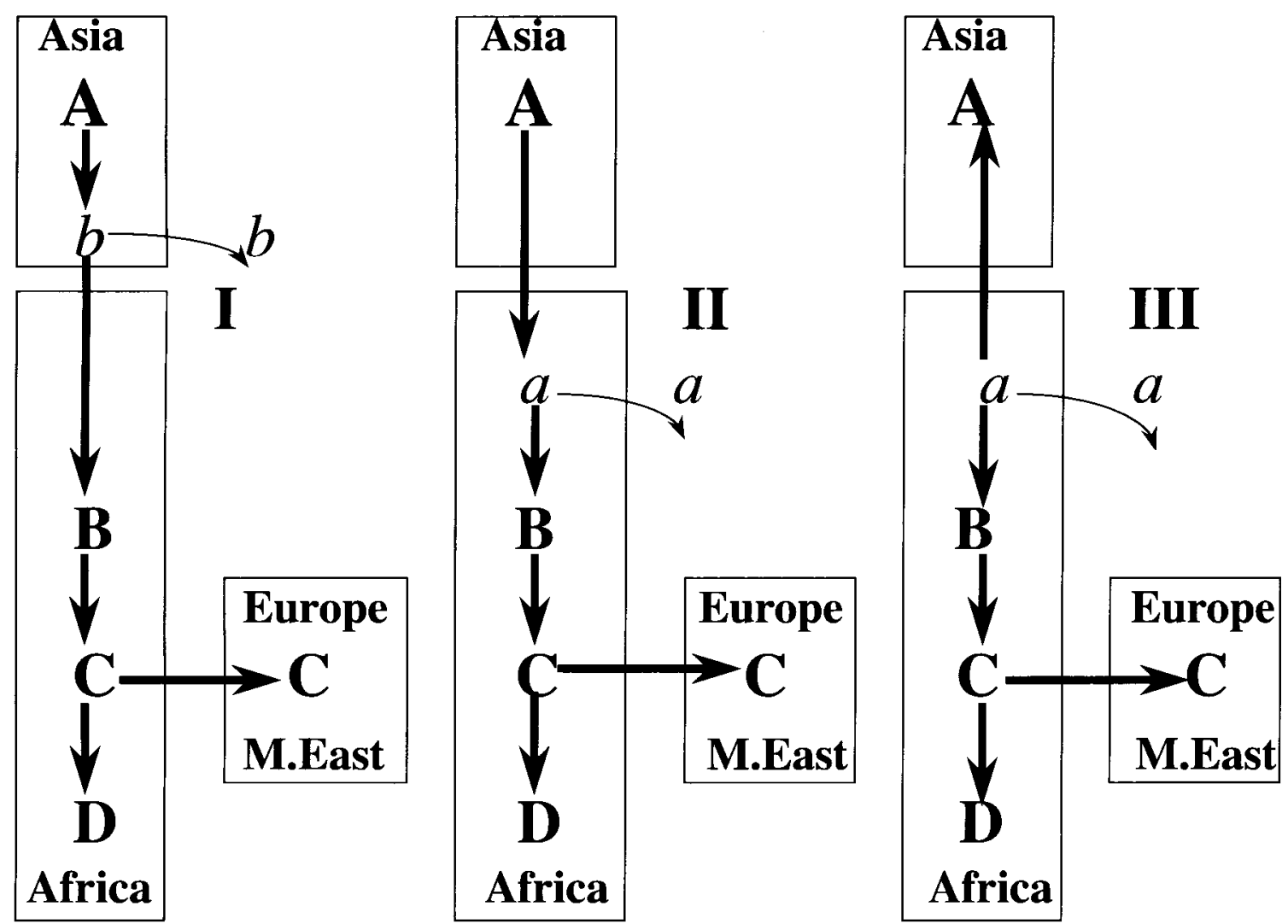

Fig.l. Evolutionary pathway of YAP+ chromosomes. A-D indicate haplogroups. A1, A2, B1, C1-C5 and D1-D6 indicate subhaplogroups. Numbers connected to each subhaplogroup indicate haplotypes. Arrows connect ancestral and derived forms. Acronyms in arrow shafts indicate mutations producing the derived forms. Two mutations connected by a bar indicate impossibility to detect the chronology of appeareance. SRY4,064 = G > A transition; $\mathrm{S}=$ PolyA tail deletion; $\mathrm{PN} 2=\mathrm{C}>\mathrm{T}$ transition; $\mathrm{D} 271=\mathrm{A}>\mathrm{G}$ transition; $\mathrm{PN} 1=\mathrm{C}>\mathrm{T}$ transition; Roman numerals correspond to ah forms (see Table 2).

Vía evolutiva de los cromosomas YAP+. A-D indican haplogrupos. A1, A2, B1, C1-C5 y D1-D6 indican subhaplogrupos. Los números conectados con cada subhaplogrupo indican haplotipos. Las flechas conectan la forma ancestral con la derivada. La sigla en la línea de las flechas indica la mutación que genera la forma derivada. Dos mutaciones unidas por una línea indica imposibilidad de datar la aparición. SRY4,064 = transición G > A; S = deleción de la cola de PolyA; PN2 $=$ transición $\mathrm{C}>\mathrm{T} ; \mathrm{D} 271$ = transición $\mathrm{A}>\mathrm{G} ; \mathrm{PN1}=$ transición $\mathrm{C}>\mathrm{T} ; \operatorname{los}$ números romanos corresponden a las formas ah (ver Tabla 2).

that no family relationship was known to exist among them. The pair of individuals showing the haplotype 13 were from the same city; however, the ancestors of one of them migrated from Galicia, Spain, whereas the ancestors of the other were Jewish. The ancestors of the two cases having the haplotype 14 were Jewish. Three of the four cases sharing haplotype 29 bore Italian family names; the fourth, however, was an Amerindian of the Wichi tribe. The analysis of the DYS 199 locus in this donor showed a $G$ base suggesting a nonAmerindian origin for his YAP+ chromosome (Bianchi et al. 1997). The five cases exhibiting haplotype 43 were AfroEcuadorians from the city of Esmeralda. African slaves were introduced into the Esmeralda region around 1762 (Coba-
Andrade 1980). Since haplogroup D is predominant in Africans (Hammer 1995, Hammer et al. 1998) we may assume that the common ancestor for cases sharing haplotype 43 can be traced to at least 10-11 generations back. Finally, one AfroAmerican and one AfroEcuadorian shared haplotype 46 , suggesting that these lineages derive from a common ancestor that probably lived in Africa before the introduction of slaves into America.

The monophyletic origin of YAP+ lineages is in good agreement with predictions of the theories formulated by von Haeseler et al. (1995) and Hardpending et al. (1998). In this regard we can envisage the evolution of YAP+ chromosomes as a chronological and hierarchical succession of 
severe bottlenecks followed by expansions. In a process of this sort, each lineage generating a haplogroup, subhaplogroup or haplotype originates in a single individual and then grows through expansion giving rise in some cases to the coexistence of the ancestral and derived lineages, to the partial or total replacement of the ancestral lineage by the derived one, or, in some occasions, to the total loss of the ancestral and derived forms. The finding of haplogroups B, C and D in Africa or subhaplogroups A1-A2 in Asia, C1-C5 in Europe, and D1-D6 in Africa are examples of coexistence of ancestral and derived forms. Lack of B haplogroups in Asia or A haplogroups in Africa (see next section) suggests total replacement of the ancestral by the derived form. S, PN2, DYS271 and PN1 variants indicate a chronological succession of four mutational steps. Yet, our series, as well as that of Altheide \& Hammer (1997) only shows cases with two (S/PN2) or four (S/PN2/DYS271/PN1) mutations, implying the total or almost total replacement of cases with one mutation by the derived forms with two mutations, and the replacement of $\mathrm{Y}$ chromosomes with three mutations by derived chromosomes with four mutations.

Geographic origin and age of YAP+ chromosomes

In regard to the geographic distribution of ancestral and derived YAP+ chromosomes, our data are in agreement with those of Hammer et al. (1997, 1998) and Altheide \& Hammer (1997). Our haplogroup A ( $3 G$ ) was restricted to greater Asians, mainly Tibetans and Japanese. Haplogroup B (3A) was mainly found in Africans. In our series, haplogroup $C$ was prevalent for Europeans while in Altheide and Hammer's series (4A) it was almost equally distributed between Europeans and Africans. Moreover, this haplogroup has also been reported in middle easterns (Hammer et al. 1997, Thomas et al. 1998). Finally, the most recent haplogroup D (5A) was mainly detected in individuals of African ancestry (Table 2).

Lately, Altheide \& Hammer (1997) proposed three models explaining the origin and evolution of YAP+ chromosomes. These models take into account the fact that the most ancestral haplogroup $A(3 G)$ is only found in Japanese and Tibetans. In the Asian founder model, it is assumed that haplogroup $A(3 G)$ originated in Asia and haplogroup $\mathrm{B}$ (3A) appeared in deme migrating into Africa with subsequent loss of haplogroup A during migration or after entering Africa. In the
Asian/Asian model, haplogroups A (3G) and B (3A) originated in Asia; after the migration of a $B$ deme into Africa, the form $B$ became extinct in the Asian area of origin. Finally, in the African model, haplogroup A emerged in Africa to become lost after migration to Asia (Altheide \& Hammer 1997, Hammer et al. 1998).

Taking into account the geographical haplogroup distribution in all continents, it is possible to reformulate the models on the origin and evolution of YAP+ chromosomes as indicated in Fig. 2.

Model I (Fig. 2, I) implies an Asian origin for ancestral and derived haplogroups $A$ and $B$, and migration of $B$ to Africa with the subsequent extinction of this haplogroup in Asia. In the model II (Fig. 2, II) the haplogroup A originated in Asia, migrated into Africa and became lost in Africa after giving rise to derived haplogroup B. In model III (Fig. 2, III), the ancestral haplogroup A appeared in Africa, migrated into Asia and became extinct in Africa following the appearance of haplogroup B. The three models (Fig. 2, I-I-III) propose an African origin for haplogroup B, C, D and the migration of $\mathrm{C}$ from Africa to Middle East and from there to Europe.

Models I, II and III require the same number of migrations, haplogroup losses and mutations. Therefore, it is difficult to decide which of these models is applicable to the early evolutionary stages of YAP+ elements.

Altheide \& Hammer (1997) favor Asia as the site of origin of the $\mathrm{Y}$-specific Alu insertion based on the detection of haplogroup A ( $3 G$ ) in Asia and not in other continents, and based on the finding of a higher genetic diversity in haplogroup $A$ (3G) when compared with the diversity of haplogroup B (3A). Since haplogroup B is a derivative form of $A$, the incresed diversity of $A$ represents an additional demonstration of ancestrality but not of geographic origin. Thus, so far, the hypothesis of the Asian origin of YAP+ chromosomes rests only on the specific Asian location of haplogroup A. Yet, the lack of ancestral YAP+ chromosomes in regions between Japan and Tibet, and Tibet and Africa is rather puzzling and makes it difficult to decide in favor of the out-of-Asia or out-of-Africa hypotheses.

The estimated age of the ancestral YAP+ chromosome may perhaps provide additional evidence on the geographical origin of the $\mathrm{Y}$-specific Alu insertion. In 1995, Hammer used five $Y$-specific biallelic markers to construct the evolutionary tree of YAP haplotypes. In that report Hammer proposed Africa as the continent of origin of the ancestral $\mathrm{Y}$ and the ancestral Y AP+ chromosomes, estimated in 188,000 years the age of the ances- 


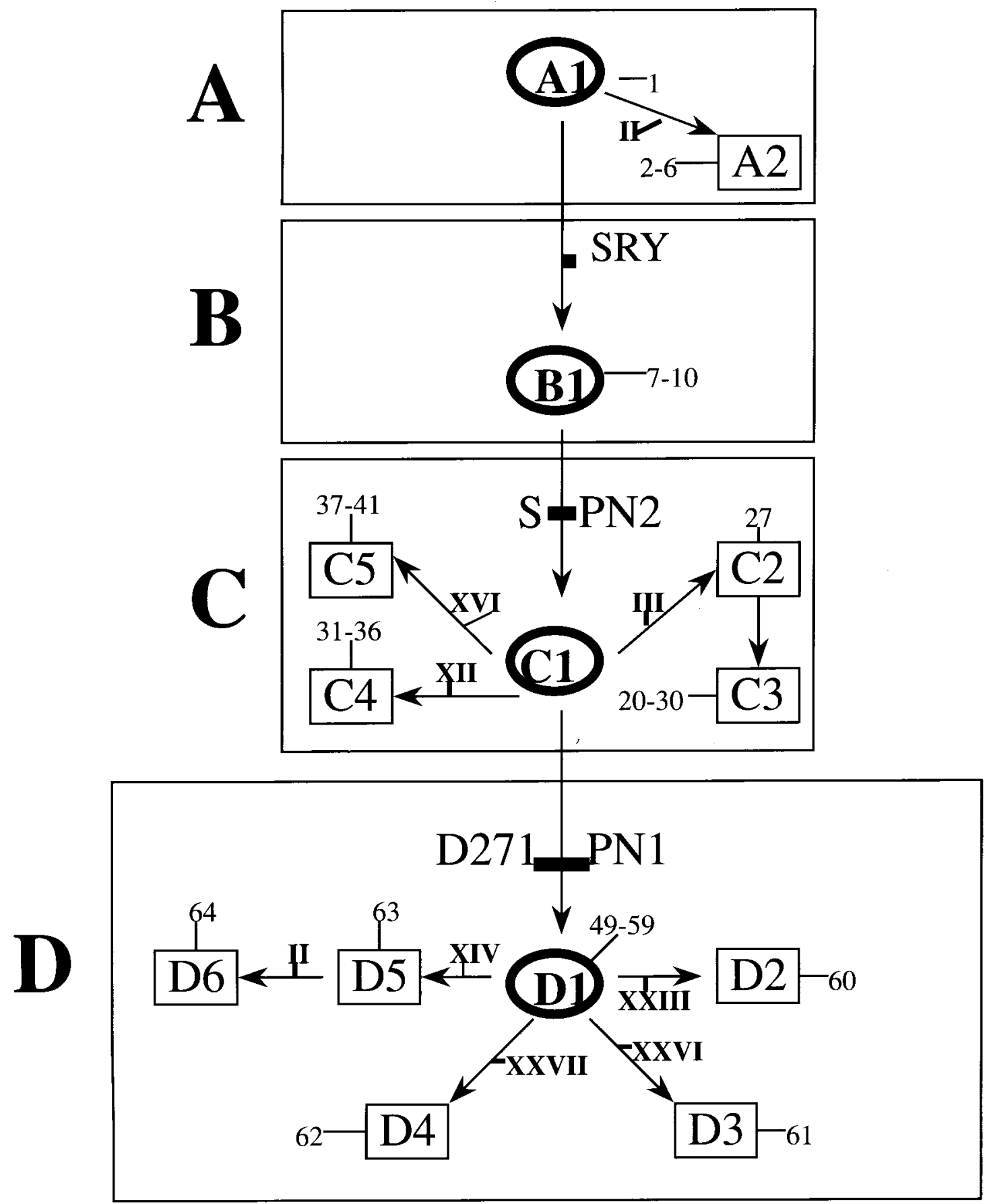

Fig. 2. Models regarding the geographical origin and evolution of YAP+ chromosomes. A-D indicate haplogroups. Low case letters with thin curved arrows indicate the geographic place of haplogroup extinction. Thick arrows connecting haplogroups indicate ancestral and derived forms. Thick arrows connecting two different areas indicate the direction of intercontinental migrations. Models I and II propose Asian origin of YAP+ chromosomes; model III proposes an African origin.

Modelos correspondientes al origen geográfico y evolución de los cromosomas YAP+. A-D indican haplogrupos. Las letras minúsculas con flecha curva delgada indican lugar geográfico de extinción del haplogrupo. Las flechas delgadas que unen los haplogrupos indican las formas ancestrales y derivadas. Las flechas delgadas que unen dos áreas distintas indican la dirección de las migraciones intercontinentales. Los modelos I y II proponen el origen asiático de los cromosomas Y AP+; el modelo III propone el origen africano. 
tral Y chromosome (95\% confidence interval of 411,000 to 51,000 years) and suggested 144,000 years ( $\pm 81,000$ years) as the age of YAP+ chromosomes; these dates were later on confirmed by Hammer et al. (1997).

Recently, Hammer's group analysed the distribution of nine (Hammer et al. 1998) and 12 (Karafet et al. 1999) Y-specific biallelic markers in a large number of individuals representing populations from Africa, Asia, Europe, Oceania and America, and defined 10 (Hammer et al. 1998) and 14 (Karafet et al. 1999) different Yhaplotypes. By using a coalescence analysis, Hammer confirmed Africa as the continent of origin of modern humans and proposed Asia as the place of origin of the ancestral YAP+ element. On the other hand, these authors estimated a later age for the origin of the ancestral $Y$ chromosome (150,000-130,000 years BP) and YAP+ chromosomes $(60,000-55,000$ years BP) (Fig. 7 from Hammer et al. 1998, and Fig. 2 from Karafet et al. 1999). A more recent origin of the Alu insert could, at first sight, be in better agreement with the hypothesis of an Asian origin of the YAP+ variant (Altheide \& Hammer 1997, Hammer et al. 1998).

In one of the above reports (Karafet et al. 1999) it is stated that the native-American-specific $\mathrm{C}>$ $T$ transition at the DYS 199 locus appeared in the New World approximately 7,600 years BP, a date representing an underestimation as there is now robust evidence indicating that DYS $199 * \mathrm{~T}$ occurred in Beringia 30,000-20,000 years BP (Underhill et al. 1996, Lell et al. 1997, Bianchi et al. 1998, Santos et al. 1999). Accordingly, it seems valid to evaluate whether the more recent origin proposed by Hammer et al. (1998) and Karafet et al. (1999) for the ancestral YAP+ element represents also an underestimation.

In monogamous populations the effective population size of autosomal genes is four times greater than those of the haploid $Y$ chromosome and mtDNA. Yet, when the mode of hereditary transmission of these two haploid systems are compared, there are clear sex-specific peculiarities that can be only explained by differences between the effective population sizes of both systems (Seielstad et al. 1998, Pérez-Lezaun et al. 1999). In the case of mtDNA, the effective population size not only encompasses the number of females with potential reproductive activity, but also the number of mtDNA molecules in the oocytes (Howell \& Mackey 1997). Thus, due to the polyhaploidy of female germ cells the effective population size of mtDNA is higher than estimated. Conversely, the increased male mortality for violent causes (big game hunting, warfare)
(Walker \& Lambert 1989, Seielstad et al. 1998) and the practice of polygyny (Pena et al. 1995, Seielstad et al. 1998) give rise to a lower effective population size than that resulting from the haploid state of the Y chromosome (Seielstad et al. 1998). Moreover, polyginy and patrilocality (tendency of females to move into the geographic area of their male reproductive partners) (Seielstad et al. 1998, Pérez-Lezaun et al. 1999) do not fit the concept of random mating.

Methods used to estimate the age of coalescence usually assume random mating and constant effective population sizes through all the evolutionary time under analysis (Hammer et al. 1998). However, as we discussed above, these two assumptions do not necessarily apply to $\mathrm{Y}$ chromosomes. On the other hand, genetic drift, population subdivision and full linkage disequilibrium of $Y$-specific markers give rise to frequent losses of paternal lineages that play an important role in the evolution of $Y$ chromosomes (Pérez-Lezaun et al. 1999). The coexistence of two biallelic mutations in the branching of the YAP+ haplogroup B into C (S and PN2, Fig. 1), and in the branching of the haplogroup $C$ into $D$ (DYS271 and PN1, Fig. 1) are two examples that very likely illustrate the extinction of paternal lineages (see previous section of Discussion). Since coalescence methods using Y-specific markers employ extant but not extinct lineages, there is a clear risk of underestimation in the ages ascribed by these techniques to ancestral and derived paternal lineages. Novel methods of age estimation of $\mathrm{Y}$ lineages have been developed to avoid the problem caused by lineages extinction (Underhill et al. 1996, Bianchi et al. 1998). Unfortunately, these methods cannot be used to date YAP+ variants due to the multiple partitioning and monophyletic origin of YAP+ haplogroups, subhaplogroups and haplotypes. Accordingly, we think valid to conclude that the age of $60,000-$ 55,000 years proposed by Hammer et al. (1998) and Karafet et al. (1999) is probably underestimated.

Lahr \& Foley (1998) have lately reviewed the geological, paleoanthropological and genetic evidence regarding the evolutionary history of $\mathrm{Ne}$ anderthals and modern humans. According to these authors the evolution of humans was strongly influenced by environmental changes produced by glaciation and interglaciation cycles. Thus, modern human ancestors very likely appeared in Africa and underwent a severe population contraction 200,000 to 130,000 years $\mathrm{BP}$, in coincidence with the maximal glacial period 6. During the initial interglacial period 5 , approximately 125,000 years BP, a marked demographic expan- 
sion led to the occupation of the savanna belt as well as southern and northern African regions. At later stages of interglacial period 5, a second population contraction gave rise to the establishment of several small modern human subpopulations in sub-Saharan and northern African regions. Then, starting 70,000 to 60,000 years BP, a number of migrations and out-of-Africa expansions led initially to the occupation of Australia through the dispersal of an eastern African population, along the Indian Ocean Rim, and at later dates to the occupation of Eurasia.

Taking into account the above scenario, the estimation of $135,000-60,000$ years BP for the appearance of the $\mathrm{Y}$-specific Alu insert (earlier dates being more likely) locates in Africa the origin of ancestral and derived $\mathrm{YAP}+$ chromosomes (Fig. 2, Model III). Migration into Asia and the subsequent extinction of the haplogroup $A$ in Africa may have occurred during the early dispersal of modern humans out of Africa. At later stages, probably 45,000 to 40,000 years BP, the migration and expansion of haplogroup $\mathrm{C}$ in Europe may have taken place. Thus, although the evidence currently available is not totally conclusive, the out-of-Africa hypothesis for the origin of YAP + chromosomes is the model better fitting the geological, anthropological and genetic data.

\section{ACKNOWLEDGMENTS}

We wish to thank all colleagues mentioned in Material and Methods who kindly provided the samples used in this report. This research was supported by grants from the National Council of Research, Argentina (CONICET), Research Commission of the province of Buenos Aires, Argentina (CIC), Argentine-Brazilian Center for Biotechnology (CABBIO), and National Agency for the Development of Science and Technology, Argentina (ANPCyT).

\section{LITERATURE CITED}

ALTHEIDE TK \& MF HAMMER (1997) Evidence for a possible Asian origin of YAP+ Y chromosomes. American Journal of Human Genetics 61: 462-466.

BATZER MA, M STONEKING, M ALEGRÍAHARTMAN, H BAZAN, DH KASS. TH SHAIKH \& GE NOVICK (1994) African origin of human-specific polymorphic Alu insertions. Proceedings of the National Academy of Sciences USA 91: 12288-12292.
BIANCHI NO, G BAILLIET, CM BRAVI, FR CARNESE, F ROTHHAMMER, VL MARTÍNEZ-MARIGNAC \& SDJ PENA (1997) Origin of Amerindian Y-chromosomes as inferred by the analysis of six polymorphic markers. American Journal of Physical Anthropology 102:79-89.

BIANCHI NO, CI CATANESI, G BAILLIET, VL MARTÍNEZ-MARIGNAC, CM BRAVI, LB VIDALRIOJA, RJ HERRERA \& JS LÓPEZ-CAMELO (1998) characterization of ancestral and derived $y$-chromosome haplotypes of new world native populations. American Journal of Human Genetics 63: 1862-1871.

BRAVI CM, G BAILLIET, JV CRISCI \& NO BIANCHI (1997a) Evolution of YAP+ human Y-chromosomes. Journal of Genetics and Molecular Biology 8: 65-69.

BRAVI CM, M SANS, G BAILLIET, VL MARTÍNEZMARIGNAC, M PORTAS, I BARRETO \& C BONILLA (1997b) Characterization of mitochondrial DNA and Y-chromosome haplotypes in a Uruguayan population of African ancestry. Human Biology 69: 64I-652.

CHAKRABORTY R (1992) Sample size requirements for addressing the population genetic issues of forensic use of DNA typing. Human Biology 64: 141-159.

COBA-ANDRADE CAG (1980) Literatura popular afroecuatoriana. Editorial Gallocapitán, Otavalo, Ecuador.

DAUSSET J, H CANN, D COHEN, M LANTHROP, JM LALOUEL \& R WHITE (1990) Centre d'Étude du Polymorphisme Humain (CEPH): collaborative genetic mapping of the human genome. Genomics 6 : 575-577.

DE KNIFF P, M KAYSER, A CAGLIA, D CORACH, N FRETWELL, C GEHRIG \& G GRAZIOSI (1997) Chromosome $\mathrm{Y}$ microsatellites: population genetic and evolutionary aspects. International Journal of Legal Medicine 110: 134-140.

HAMMER MF (1994) A recent insertion of an Alu element on the $Y$ chromosome is a useful marker for human population studies. Molecular Biology and Evolution 11: 749-761.

HAMMER MF (1995) A recent common ancestry for human Y chromosomes. Nature 378:376-378.

HAMMER MF \& S HORAI (1995) Y chromosomal variation and the peopling of Japan. American Journal of Human Genetics 56: 951-962.

HAMMER MF, AB SPURDLE, T KARAFET, MR BONNER, ET WOOD, A NOVELLETTO \& $P$ MALASPINA (1997) The geographic distribution of human Y chromosome variation. Genetics 145: 787 805.

HAMMER MF, T KARAFET, A RASANAYAGAM, ET WOOD, TK ALTHEIDE, T JENKINS \& RC GRIFFITHS (1998) Out of Africa and back again: nested cladistic analysis of human $Y$ chromosome variation. Molecular Biology and Evolution 15: 427441.

HARPENDING HC, MA BATZER, M GURVEN, LB JORDE, AR ROGERS \& ST SHERRY (1998) Genetic traces of ancient demography. Proceedings of the National Academy of Sciences USA 95: 1961-1967. 
HOWELL N \& D MACKEY (1997) Reply to Macauley et al. American Journal of Human Genetics 61: 986-990.

KARAFET T, SL ZEGURA, J VUTURO-BRADY, O POSUKH, L OSIPOVA, V WIEBE \& F ROMERO (1997) Y-chromosome markers and trans-Bering Strait dispersals. American Journal of Physical Anthropology 102: 301-314.

KARAFET TM, SL ZEGURA, O POSUKH, L OSIPOVA, A BERGEN, J LONG \& D GOLDMAN (1999) Ancestral Asian source( $s$ ) of New World Y-chromosome founder haplotypes. American Journal of Human Genetics 64: 817-831.

KLEIN RG (1992)The archeology of modern human origins. Evolution and Anthropology 1: 5-15.

KAYSER M, A CAGLIA, D CORACH, N FRETWELL, C GEHRIG, G GRAZIOSI \& F HEIDORN (1997) Evaluation of Y-chromosomal STRs: a multicenter study, International Journal of Legal Medicine 110: 125 133.

LAHR MM \& RA FOLEY (1998) Towards a theory of modern human origins: geography, demography, and diversity in recent human evolution. Yearbook of Physical Anthropology 41: 137-176.

LELL JT, MD BROWN, TG SCHURR, RI SUKERNIK, YB STARIKOVSKAYA, A TORRONI \& LG MOORE (1997) $Y$ chromosome polymorphisms in Native American and Siberian populations: identification of Native American Y chromosome haplotypes. Human Genetics 100: 536-543.

PASSARINO G, O SEMINO, L QUINTANA-MURCI, L EXCOFFIER, MF HAMMER \& AS SANT ACHIARABENERECETTI (1998) Different genetic components in the Ethiopian population, identified by mtDNA and $\mathrm{Y}$-chromosome polymorphisms. American Journal of Human Genetics 62: 420-434.

PENA SDJ, FR SANTOS, NO BIANCHI, CM BRAVI, FR CARNESE, F ROTHHAMMER \& T GERELSAIKHAN (1995) Identification of a major founder Y-chromosome haplotype in Amerindians. Nature Genetics 11: 15-16.

PÉREZ-LEZAUN A, F CALAFELL, D COMAS, E MATEU, E BOSCH, R MARTÍNEZ-ARIAS, J CLARIMON \& G FIORI (1999) Sex-specific migration patterns in Central Asian populations, revealed by analysis of $\mathrm{Y}$-chromosome short tandem repeats and mtDNA. American Journal of Human Genetics 65: 208-219.

SANS M, TA WEIMER, SC FRACAK, MHLP FRANCO, FM SALZANO, N BENTANCOR \& I ÁLVAREZ (in press) Unequal contributions of male and female gene pools from parental populations in the African descendants of the city of Melo, Uruguay. American Journal of Physical Anthropology.

SANTOS FR, NO BIANCHI \& SDJ PENA (1996) Worldwide distribution of human $Y$-chromosome haplotypes. Genome Research 6: 601-611.

Invited Editors: R. Godoy-Herrera and G. Gajardo Received April 15, 2000; accepted September 18, 2000
SANTOS FR, A PANDYA, C TYLER-SMITH, SDJ PENA, M SCHANFIELD \& WR LEONARD (1999) The Central Siberian origin for native American Y chromosomes. American Journal of Human Genetics 64: 619-628.

SCHMID C \& R MARAIA (1992) Transcriptional regulation and transpositional selection of active SINE sequences. Current Opinion in Genetics \& Development 2:874-882.

SEIELSTAD M, JM HERBERT, AA LIN, PA UNDERHILL, M IBRAHIM, D VOLLRATH \& LL CAVALLI-SFORZA (1994) Construction of human Y-chromosomal haplotypes using new polymorphic A to $\mathrm{G}$ transition. Human Molecular Genetics 3: 2159 2161.

SEIELSTAD M, E MINCH \& LL CAVALLI-SFORZA (1998) Genetic evidence for a higher female migration rate in humans. Nature Genetics 20: 278-280.

SEIELSTAD M, E BEKELE, M IBRAHIM, A TOURE \& M TRAORE (1999) A view of modern human origins from Y chromosome microsatellite variation. Genome Research 9: 558-567.

SPURDLE AB, MF HAMMER \& T JENKINS (1994) The $Y$ Alu polymorphism in Southern African populations and its relationship to other $\mathrm{Y}$-specific polymorphisms. American Journal of Human Genetics 54: 319-330.

STONEKING M, JJ FONTIUS, SL CLIFFORD, H SOODYALL, SS ARCOT, N SAHA \& T JENKINS (1997) Alu insertion polymorphisms and human evolution: evidence for a larger population size in Africa. Genome Research 7: 1061-1071.

THOMAS MG, K SKORECKI, H BEN-AMI, T PARFITT, N BRADMAN \& DB GOLDSTEIN (1998) Origins of Old Testament priests. Nature 394: 138-140.

UNDERHILL PA, L JIN, R ZEMANS, JP OEFNER \& LL CAVALLI-SFORZA (1996) A pre-Columbian Y chromosome-specific transition and its implications for human evolutionary history. Proceedings of the National Academy of Sciences USA 93: 196-200.

UNDERHILL PA, L JIN, AA LIN, S QASIM MEHDI, T JENKINS, D VOLLRATH \& RW DAVIS (1997) Detection of numerous Y chromosome biallelic polymorphisms by denaturing high-performance liquid chromatography. Genome Research 7: 996-1005.

VON HAESELER A, A SAJANTILA \& S PÄÄBO (1995) The genetical archaeology of the human genome. Nature Genetics 14: 135-140.

WALKER PL \& P LAMBERT (1989) Skeletal evidence for stress during a period of cultural change in prehistoric California. In: Capasso L (ed) Advances in Paleopathology: 207-212. National Archaeological Museum, Pisa, Italy.

WHITFIELD LS, JE SULSTON \& PN GOODFELLOW (1995) Sequence variation of the human Y chromosome. Nature 378: 379-380. 